\title{
Akkaraman kuzu rasyonlarına farklı oranlarda katılan çay atıklarının bazı verim özelliklerine etkileri*
}

\author{
Halit İMIK', Şakir Doğan 'TUNCER², Aylin AYLANÇ3, Melik AYTAC ${ }^{3}$, İsmail ERDOC̆AN ${ }^{3}$ \\ 1 Atatijk Universitesi. Veteriner Fakiiltesi, Hayvan Besleme ve Beslenme Hastahlkları Anabilim Dalı. Erzurum: ' Ankarit

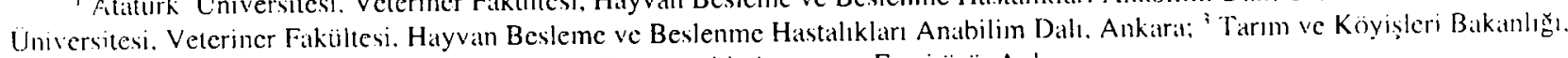 \\ Lalahan Hayvancılık Araştırma Enstitiisii. Ankiara
}

\begin{abstract}
Özet: Bı çalısmada. kaba yem olarak yulaf hasılı yerine kullanılan f̧ay atıklarımın, kuzularda canlı ağ

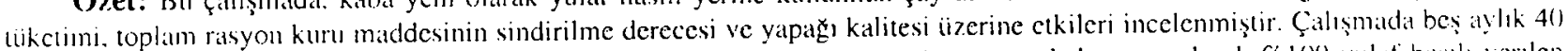
baș erkek Akkaraman kuzu kullanılmış ve deneme 56 gün sürdürülmüștü. Araşurma. kaba yem olarak \% $1(0)$ yulat hasilı verılen

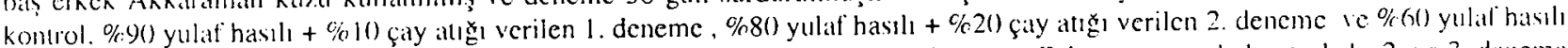

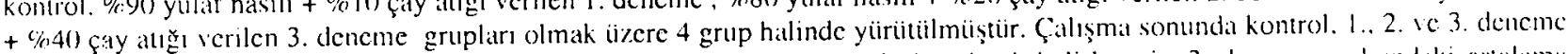

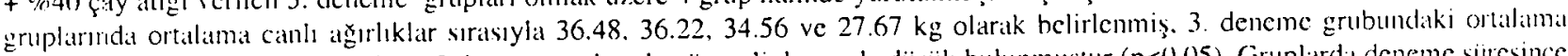
canlı jă

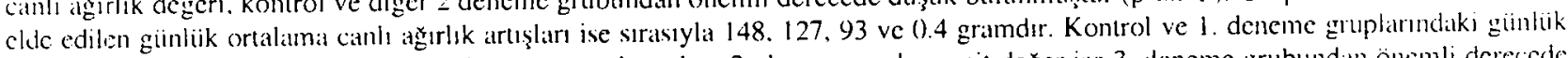
orlitama canl, as̆ırlık artısları 2. ve 3. deneme gruplarından; 2. deneme grubuna ait değger ise 3. deneme grubundan önemli derecede yikssck bulummusulur $(p<0)(15)$. Gruplarda toplam rasyon kuru maddesinin sindirilme dereceleri sirasiyla \%64.67. 69.95. 49.61 ve

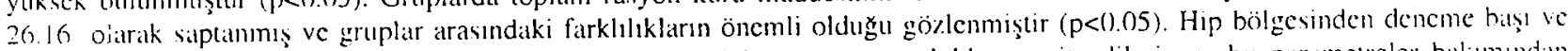
deneme sununda alınan yapatŏ numunelerinde incelik, ondulasyon ve uzunluklar tespit edilmiş ve bu parameureler bakimindan

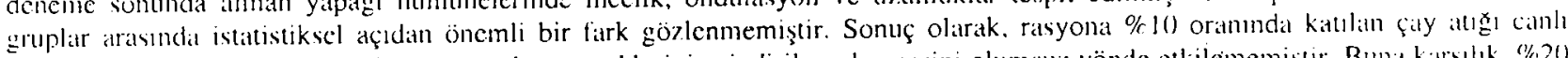

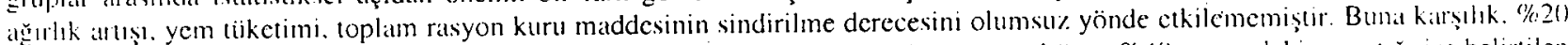
oranndaki f̧ay atı̆̆ toplam rasyon kuru maddesinin sindirilme derecesi ile hayvan sağ

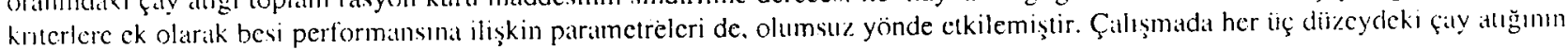

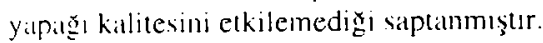

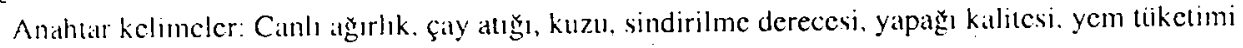

\section{The effect of tea wastes added to the rations of Akkaraman lambs on some performance parameters}

Summary: In this study. the effects of tea wastes used instead of oat haty on the live weight giin. forige consumption. diacstibility of total dry matter of fecds and mohair quality in lambs werc examined. In the experiment. 40 Akkaraman laumbs with 5 months old were used. The research works were conducted in 4 groups for the period of 56 days. The groups were fed with $10(1) \%$ oat

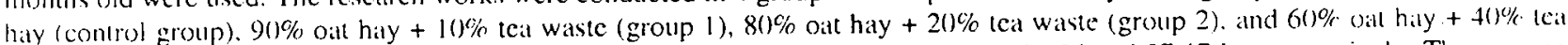
$w_{\text {ilste }}$ (group 3). At the end of the study, the average live weights were $36.48,36.22 .34 .56$ and $27.67 \mathrm{~kg}$, respectively. The average live weight in the group 3 was significantly lower than that of the others $(p<0.05)$. The average daily live weight gains of the groups were 148, 127.93 and ().4 $\mathrm{E}$, respectively. The average daily live weight gains of control group and the group 1 were higher thill that of group 2 and group 3, in addition the average daily live weight gain of group 2 was higher than that of group 3 ( $p<0$ ). (15). The digestibility rates of total dry mitter in the groups were $64.67 \%, 69.95 \%, 49.61 \%$ and $26.16 \%$, respectively. There were significant differences atmong the groups in terms of digestibility rates $(p<0) .(05)$. The mohair quality in samples oblatined from hip areal was decrmined at the beginning and end of the study. There were no statistically differences anong the groups in mohatir yuality. As a result. there was no. negative effect of the teat wastes added at the rate of $10 \%$. on live weigth gain. feed intike. digestibility of total dry matter. 2()\% of the tea wastes has a negative effect on digestibility of total dry matter and animal health. $4(1) \%$ of the ical wastes hiis at newative elfect on performance parancters, digestibility of total dry matter and animal health. It can be rought thall the teal wisics has no effect on wool quility.

Key words: Digestibility, fecd consumption. lamb, live weight, teat wastes. wool quality

\section{Giriş}

Cay yapraklarmm yapısunda bulunan ham besin maddeleri miktarı bazı araşturıcilar tarafindan incelennniştir. Nitekim. Sud ve ark. (18) çay yapraklarının ham protein (HP) değerini \%29.93, hücre duvarı içcriğini $\% 51.08$; seliiloz miktarını ise \%11.53 olarak belirlemiş- lerdir. Aynı araştırıcılara göre yapraktaki nöıal deıcrjan fiber (NDI'), asit deterjan fiber (ADI) ve asit decerjan lignin (ADL) değerleri ise sirasiyla \%48.92. \%29.54 ve $\% 17.09$ 'dur. Kunjikutty ve ark. (15) yapukları analizlerde çay atığında ham protein, ham yağ (HY), ham scliilo\% (HS), ham kül (HK) miktarların sırasıyla $\% 29.3$, \% $\% 7.4$.

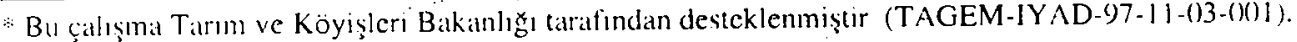


\%14.1 ve \%3.8 olarak belirlemişlerdir. Imik ve Şeker (10) ise çay atıklannın ham besin madde analizlerinde kuru maddc, HP, HY, HK ve HS değerlerini sirasıyla $\% 94.52$. \%12.87, \%1.14, \%5.04 ve \%31.93 olarak bildirirken, azotsuz öz maddeyi \%43.54, NDF'yi \%56.41, ADF'yi \%46.30, ADL'yi \%22.26, hemisellülozu \%10.11 ve sellülozu ise \%24.04 olarak tespit etmişlerdir.

Çay Işletmeleri Genel Müdürlügüu 1992-1996 yıllan arasında üreticilerden 2.664 .000 ton yaş çay yaprağı toplandığını ve üretim aşamasında yaklaşık 60.000 ton çay aıklarının elde edildiğini bildirmektedir (2). Bunun dlşında, özel çay fabrikalarında da bu miktara yakin yaprağın işlenmesi sonucu önemli miktarda atık ortaya çımaktadır. Çay üretimi sırasında elde edilen atıkların sunta yapımı gibi değişik amaçlar için kullanılmasına çalışılmış ancak uygulama pahalı olduğundan pratige aktarılamamıştır.

Çay atıklarının bileşininde kafein ve tanen gibi bileşikler bulunmaktadır. Imik ve Şeker (10) çay fabrikasyon atıklannın kuru maddesinde tanen miktannı \%.7.89 olarak saptamışlardır. Konwar ve ark. (14) ise çay fabrikası atıklarında tannik asit ve kafein miktarlarının sırasiyla \%6.3 ve \%3. I olduğunu bildirmişlerdir.

Hayvanlar tanen içeren yem maddelerine karşı farklı şekillerde duyarlılık göstermektedirler. Begoviç ve ark. (5) keçilerin rumenlerinde bulunan tannaz aktivesi ncdeniyle \%8-10 düreyindeki taneni tolere edebildiklerini, bu oranın sığırlarda \%3-5, kanathlarda ise \%1 oldugunu ileri sürmiişlerdir.

Baruah (4) süıçü melez sığırların (Jersey x Assam) rasyonunda yer alan $\% 35$ oranındaki buğday kepeğinin yerine \%20 buğday kepeği + \%15 çay atıklarının (kafeini çıkartılmış) kombinasyonunun kullanılmasının hayvanların gelişmesi, süt verimi ve süt bileşimi üzerinde olumsuz etki yapmadığını bildirmiştir.

Bu çalışma, rasyonlarda kaba yem olarak kullanılan yulaf hasılımın yerine değişik oranlarda katılan çay atıklarının Akkaraman kuzularda canlı ağırlık arışı, yem tüketimi, toplan rasyon kuru maddenin sindirilme derecesi ile yapağı kalitesine etkilerini belirlemek amacıyla yapılmışır.

\section{Materyal ve Metot}

\section{Hayvan materyali}

Lalahan Hayvancılık Araştırma Enstitüsü'nde yürütülen bu çalışmada aynı Enstitü'den saglanan 5 aylık toplam 40 baş Akkaraman kuzu kullanılmıştır. Her biri 10 baş kuzudan oluşan bir kontrol ve 3 deneme olmak iizere toplam 4 grup halinde yürütuilen araştırmada hayvanlar gruplara tesadüfi olarak dağıtılmıştır. Calışma 10 günlük alıştırma ve 56 günlük deneme ciönemi olmak üzere iki dönem halinde yürütülmüuştür.

\section{Yem materyali}

Çalışmada kaba yem olarak kullanılan çay aukları Rize Çaykur Kendirli Çay Fabrikası'ndan. yulaf hasılı ile konsantre yemin yapısına giren arpa Lalahan Hayvancilik Araştırma Enstitüsü'nden, ayçiçeği küspesi, kepek, kireçtaşı ile vitamin ve mineral karmalan piyasadan temin edilmiştir.

Grup yemlemesi yapılan çalışmada kontrol ve de neme gruplarına bileşimi Tablo l'de gösterilen konsantre yem verilmiştir. Kontrol grubuna kaba yem olarak verilen yulaf hasılının azaltılan miktan yerine deneme gruplarında artan miktarlarda çay atıkları ile homojen bir şekilde kanşurılarak kullanılmıştır (sırasıyla \%10. \%20 ve \%40). Uygulama Tablo 2'de gösterilmiştir.

\section{Hayvanların beslenmesi}

Denemede grup yemlemesi uygulanmış olup kaba ve konsantre yemler farklı yemliklerde tüketime sunulmuştur. Kaba yemlerin mümkün olduğunca fazla tiiketilmelcrini sağlamak amaciyla konsantre yemler hayvanlara canlı ağırlıklarının \% 1.5 'u ile sinırlandırılarak verilmiştir. Kaba yemler tüm gruplara ad libitum olarak verilmiştir. Diğer taraftan suluklarda temiz içme suyu devamlı bulundurularak hayvanların istedikleri zaman su içmelerine imkan sağlannıştır.

\section{Rasyonların besin maddeleri ve enerji düzeylerinin belirlenmesi}

Çalışmada kullanılan konsantre yemlerin yapısına giren ham maddelcrin besin maddcleri miktarları AOAC'de (3) bildirilen yöntemlerle, ham selüloz miktarı ise Crampton ve Maynard (7)'a görc tayin edilmiştir. Ayrıca, yulaf hasılı ve çay atıklanının tanen içerikleri Folin Denis solüsyonları kullanılarak Ankara Üniversitesi Veteriner Fakültesi Farmakoloji Anabilin Dah laboratuvarında yapılmıştır (3).

\section{Canlı ağırlık ve canlı ağırlık artışının belirlenmesi}

Denemede hayvanlar, canlı ağırlık ile guinliik canlı ağırlık artışlarının belirlenmesi amacı ile iki haftada bir aç karnına tartılmışlardır.

\section{Yem tüketimi vé yemden yararlanma oranının belirlenmesi}

Denemede artan yemler toplanarak 14 günde bir tartılmış ve böylece hayvanların yem tuiketimleri belirlenmiştir. Grupların yem tüketimleri ve canlı ağırlık artışı değerlerinden yararlanılarak yemden yararlannia oranı saptanmıştır.

Akkaramıan kuzulardan denemenin başında sıl, denemenin sonunda ise sağ taraftan son kostaları ile açlık çukurluğu arasından yan otomatik makinalar ile alınan yapağı numuneleri Lalahan Hayvancilık Araştırma Enstitüsü'ne ait Tiftik ve Yapağı laboratuvarlarında yapağı 
Tablo I Araşurmada kullanulan konsantre yemin bileşimi Table 1.The composition of concentrate feed used in the ex periment.

\begin{tabular}{ll}
\hline Yem maddesi & $\%$ \\
\hline Ayçiçeđ̧i kïspesi & 21 \\
Arpa & 68 \\
Kepck & 9 \\
Kireç tà̧ı & 1.5 \\
Viı + Min karması. & 0.5 \\
\hline
\end{tabular}

:5 kg karışımda yer alan (Tarvan Katık SB-5): A vifamini 6.666 .675 IÜ. D3 vitamini 666.670 IÜ, E vitamini g galsiyum $929 \mathrm{~g}$, fosfor $603 \mathrm{~g}$, magnezyum $150 \mathrm{~g}$, selényum 125 $\mathrm{mg}$. iyot $410 \mathrm{mg}$. kobalt $300 \mathrm{mg}$, demir $25 \mathrm{~g}$, bakı $5 \mathrm{~g}$, çinko 30 g. mangan $25 \mathrm{~g}$, azot $100 \mathrm{~g}$ ve küikürt $36 \mathrm{~g}$ 'dır.

Tablo 2. Araștırmada gruplara verilen kaba yem oranları, \%. Table 2. The roughage ratio used in the study, $\%$.

\begin{tabular}{lcccc}
\hline Kaba yem & & \multicolumn{3}{c}{ Deneme gruplart } \\
\cline { 3 - 5 } & Kontrol grubu & 1 & 2 & 3 \\
\hline Yulaf hasilı & 100 & 90 & 80 & 60 \\
Çay attilar & 6 & 10 & 20 & 40 \\
\hline
\end{tabular}

özellikleri açısından (uzunluk, incclik, ondulasyon, kemp ve medưlla) incelenmişlerdir (9).

Toplam rasyon kuru maddesinin sindirilme derecesinin tespitinde indikatör olarak asitte erimeyen kül kullanılmıştır (19). Bu amaçla denemenin son üç gününde her hayvandan ayrı olarak dışkı örnekleri alınmış ve bunlar kuru madde, ham kül ve asittc erimeyen kül analizlerine: kadar derin dondurucuda saklanmıştır.

Denemede ölüm kayıtları tutulmuştur.

Araşırmadan elde edilen veriler varyans analizine tabi tutulmuş, farklı olan değerlere Duncan testi uygulanmıştır (8)

\section{Bulgular}

Araştı mada konsantre yemin bileşinịne giren ham maddeler ile kaba yem olarak kullanılan yulaf hasılı ve çay aıklarmun ham besin madde değerleri Tablo 3'de gösterilmiştir.
Tablo 3. Konsentre ve kaba yem maddclcrinin ham besin madde içcrikleri, \%

Table 3. Vutrient contents of feedstuffs, \%.

\begin{tabular}{llllll}
\hline $\begin{array}{l}\text { Yem } \\
\text { maddesi }\end{array}$ & $\begin{array}{l}\text { Kuru } \\
\text { madde }\end{array}$ & $\begin{array}{l}\text { Ham } \\
\text { protein }\end{array}$ & $\begin{array}{l}\text { Ham } \\
\text { yade }\end{array}$ & $\begin{array}{l}\text { Ham } \\
\text { selliiloz }\end{array}$ & $\begin{array}{l}\text { Ham } \\
\text { kijl }\end{array}$ \\
\hline Arpa & 87.80 & 10.82 & 1.94 & 4.60 & 2.30 \\
AÇK & 87.52 & 31.04 & 3.84 & 20.15 & 8.01 \\
Buğday & & & & & \\
kepegi & $85.60)$ & 16.12 & 3.25 & 12.41 & 4.52 \\
Çay atıkları & 93.02 & 14.38 & 1.116 & 34.75 & 4.38 \\
Yulaf hasıl & 92.38 & 10.66 & 1.55 & 26.37 & 7.74 \\
\hline
\end{tabular}

Tablo 4. Araşurmada kullanılan kaba yemlerin tanen miktarları, ppm.

Table 4. The tannen content of roughages lused in the experiment, ppm.

\begin{tabular}{lc}
\hline Ycm maddcleri & Tancn miktarı \\
\hline Yulaf hasıl & 2.58 \\
Çay atıkları & 13.9 \\
\hline
\end{tabular}

Denemede kullanılan çay atığı ve yulaf hasılının tanen içerikleri Tablo 4'de verilmiştir.

Deneme süresince kuzularda belirlenen canlı ağırlık ortalamaları Tablo 5 ve Şekil I'de gösterilmiştir. Buna göre, 3. deneme grubunda elde edilen ortalama canlı ağırlık değcri kontrol ve diğer deneme gruplanna ait ve rilerden önemli derecede düşük bulunmuştur ( $p<0.05$ ).

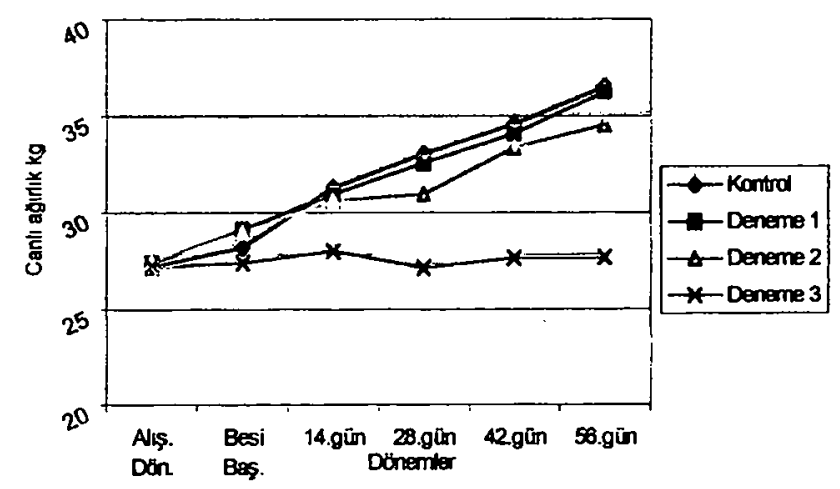

Şekil 1. Grupların canlı a.̊rılık ortalamaları. kg Figure 1. Mean live weight of groups, $\mathrm{kg}$.

Tablo 5. Grupların canlı ağırlık ortalamaları. kg.

Table 5. Mean live weight of groups, $\mathrm{kg}$.

\begin{tabular}{|c|c|c|c|c|c|c|c|c|}
\hline \multirow[b]{2}{*}{ Döncmler } & \multirow[b]{2}{*}{$\mathrm{n}$} & \multicolumn{7}{|c|}{ Dencme grupları } \\
\hline & & Kontrol grubu & $\mathrm{n}$ & 1 & $n$ & 2 & $\mathrm{n}$ & 3 \\
\hline Alsş dön. & 10 & $27.18 \pm 1.05$ & 10 & $27.38 \pm 1.00$ & 10) & $27.42 \pm 1.04$ & 10 & $27.15 \pm 1.21$ \\
\hline Besi baş. & 10 & $28.21 \pm 1.199$ & 10 & $29.13 \pm 1.05$ & 10) & $28.99 \pm 1.07$ & 10 & $27.38 \pm 1.23$ \\
\hline 14. gìn & 10 & $31.29 \pm 1.14$ & 10 & $30.94 \pm 1.23$ & 10 & $30.64 \pm 1.04$ & 10 & $28.00 \pm \pm 1 .(1) 5$ \\
\hline 28. güı & 10 & $33.04 \pm 1.19 \mathrm{at}$ & 10 & $32.57 \pm 1.13 a$ & 9 & $30.94 \pm 1.31 \mathrm{a}$ & 10 & $27.10 \pm 1.28 \mathrm{~b}$ \\
\hline 42. güin & 10 & $34.58 \pm 1.13 \mathrm{a}$ & 10) & $34.11 \pm 1.11 \mathrm{a}$ & 8 & $33.36 \pm 1.18 a$ & 9 & $27.62 \pm 1.45 b$ \\
\hline 56. giin & 10) & $36.48 \pm 1.21 \mathrm{a}$ & 10 & $36.22 \pm 1.21 \mathrm{a}$ & 8 & $34.56 \pm 1.36 \mathrm{a}$ & 9 & $27.67 \pm 1.48 b$ \\
\hline
\end{tabular}

Aym satırda farklı harfi taşıyan değerler birbirinden farklı bulunmuştur $(p<0.05)$. 
Tablo 6. Grupların ortaliama canlı ăğrlık artsşı, g/guin.

Table 6. Mean live weight gain of groups, g/day.

\begin{tabular}{lllll}
\hline & & \multicolumn{3}{c}{ Deneme gruplari } \\
Giinler & Kontrol grubu & 1 & 2 & 3 \\
\hline $0-14$ & $220 \pm 14.8 \mathrm{a}$ & $129 \pm 21.1 \mathrm{~b}$ & $118 \pm 11.1 \mathrm{~b}$ & $+4 \pm 32.7 \mathrm{c}$ \\
$14-28$. & $125 \pm 10.8 \mathrm{a}$ & $116 \pm 14.5 \mathrm{a}$ & $35 \pm 23.9 \mathrm{~b}$ & $-64.29 \pm 42.2 \mathrm{c}$ \\
$28-42$ & $110 \pm 9.3 \mathrm{a}$ & $110 \pm 10.3 \mathrm{a}$ & $118 \pm 22.5 \mathrm{a}$ & $11 \pm 310 \mathrm{~b}$ \\
$42-56$ & $136 \pm 18.7 \mathrm{a}$ & $151 \pm 21.0 \mathrm{a}$ & $86 \pm 23.8 \mathrm{a}$ & $3 \pm 27.9 \mathrm{~b}$ \\
$0-56$ & $148 \pm 7.4 \mathrm{a}$ & $127 \pm 6.9 \mathrm{a}$ & $93 \pm 11.1 \mathrm{~b}$ & $0.4 \pm 10.5 \mathrm{c}$ \\
\hline
\end{tabular}

Aym satırda farklı harli taş̧yan değgerler birbirinden farklı bulunmuştur $(p<() .(15)$.

Tablo 7. Gruplarda ortalama kaba ve konsantre yem tükctimleri. g/gün.

Table 7. Meall roughige and concentrate consumption of groups, g/dity.

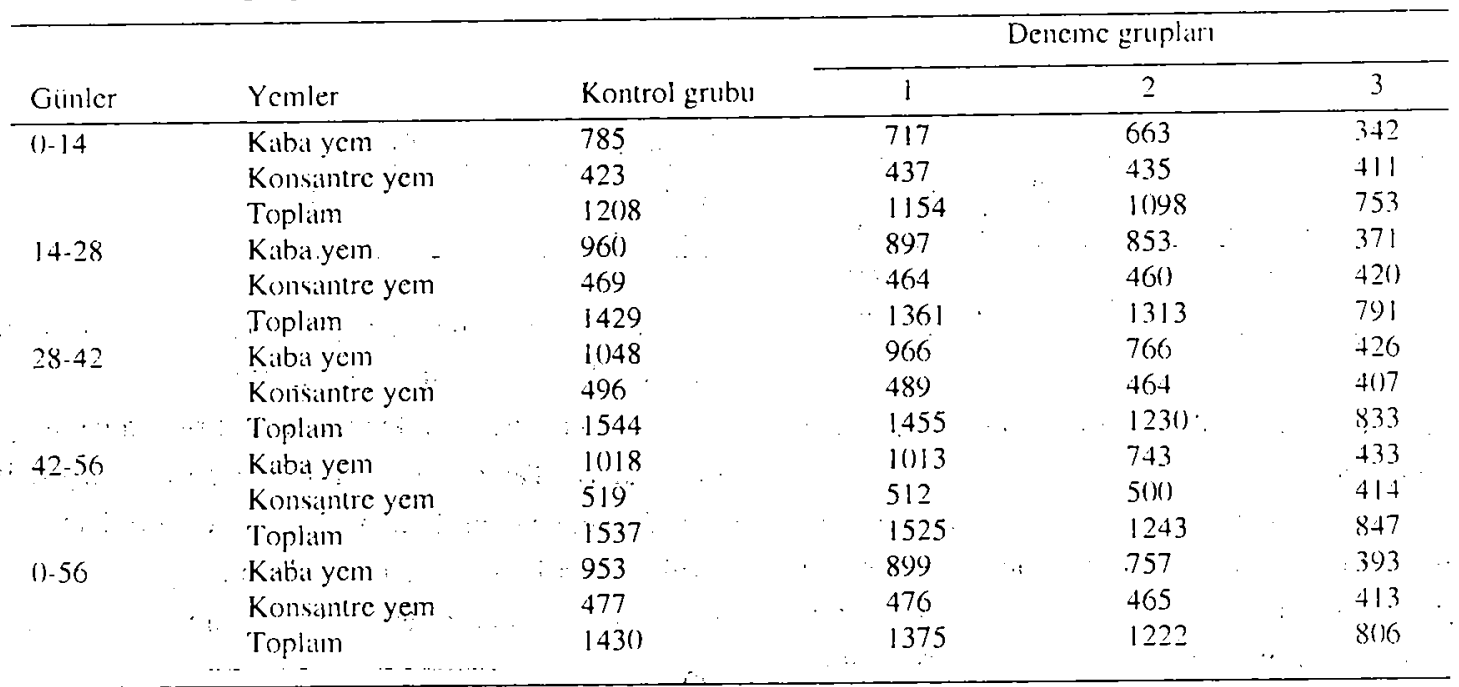

Tablo 8. Gruplara ạ̣ yemden yarạrlanma değerleri.* I,

Table 8. Mean feed efficiency vilues of groups.

\begin{tabular}{|c|c|c|c|c|c|c|}
\hline \multirow{2}{*}{ G Guinler } & \multirow[b]{2}{*}{ Yemler } & \multirow{2}{*}{$\because \because{ }_{x}$} & \multirow{2}{*}{ Kontrol grubu } & \multicolumn{3}{|c|}{ Deneme grupları. } \\
\hline & & & & 1 & 2 & 3 \\
\hline \multirow{3}{*}{$\therefore \quad 0-14$ giin } & Kaba yem & $\ldots \ldots$ & 3.568 & 5.558 & 5.619 & 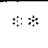 \\
\hline & Konsantre yem & & 1.923 & 3.388 & 3.686 & $\because *$ \\
\hline & Toplam & & 5.491 & 8.946 & 9.305 & $\approx *$ \\
\hline \multirow[t]{3}{*}{ 14-28. guin } & $-\cdots$ Kaba ycm & $\cdot$ & $7: 680$ & 7.733 & 24.371 & $\because n$ \\
\hline & 'Konsantre yem' & : & 3.752 & 4.000 & 14.0000 & $+x$ \\
\hline & Toplam & & 11432 & 11.733 & 38.371 & $\therefore:$ \\
\hline \multirow[t]{3}{*}{ 28-42. giin } & Kabat yem & & 9.527 & 8.782 & 6.492 & $\because \%$ \\
\hline & Konsantre yem & & 4.509 & 4.445 & 3.932 & $\theta:$ \\
\hline & Toplam & & $14 .(136$ & 13.227 & 10.424 & 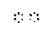 \\
\hline \multirow[t]{3}{*}{ 42-56. giin } & Kaba ycm & & 7.485 & 6.709 & 8.640 & $\because \div$ \\
\hline & Konsintre yem & & 3.816 & 3.907 & 5.814 & $\therefore$ \\
\hline & Toplam & & 11.301 & 10.616 & 14.454 & $\because n$ \\
\hline \multirow[t]{3}{*}{ (1)-56. giin } & Kaba yem & & 6.439 & 7.079 & 8.8112 & $\because$ \\
\hline & Konsantre yem & & 3.223 & 3.748 & 5.000 & $\because:$ \\
\hline & Toplaun & & 9.662 & 10.827 & 13.802 & $\therefore:$ \\
\hline
\end{tabular}

\footnotetext{
"Bir k" canlı a toğılık artışı için tüketilen yem miktarı, kg

*Canlı ăğ

I lsiallikscl analiz yapılmamıştır.
}

Araşırmann 0-56. günlerinde günlük canlı ağıllık artışlan kontrol ve deneme gruplarında sırasıyla 148, 127 , 93 ve $0.4 \mathrm{~g}$ olarak tespit edilmiş̧tir.

Kontrol ve 1. deneme gruplarına ai: değerler arasunda istatistiksel açıdan önemli bir fark gözlenememiş
( $>00.05)$, buna karş1lık her iki grup 2. ve 3. deneme gruplarından önemli derccede yiiksek cimlı ağırlık artıß sağlamışlardır ( $\mathrm{p}<0.05$ ) (Tablo 6).

Gruplarda tiiketilen kaba ve konsantre yem miktarları Tablo 7'de verilmiştir. Yulaf hasılı yerine \%40 ora- 
Tablo 9. Toplam rasyon kuru maddenin sindirilme derecesi, $\%$.

Table 9. The digestibility of total dry matter, $\%$.

\begin{tabular}{|c|c|c|c|c|c|c|c|c|}
\hline \multirow[b]{2}{*}{ Dönemler } & \multirow[b]{2}{*}{$n$} & \multirow[b]{2}{*}{ Kontrol grubu } & \multicolumn{3}{|c|}{ Deneme grupları } & \multirow[b]{2}{*}{2} & \multirow[b]{2}{*}{17} & \multirow[b]{2}{*}{3} \\
\hline & & & $\mathrm{n}$ & 1 & $n$ & & & \\
\hline $\begin{array}{l}\text { Toplam kuru maddenin } \\
\text { sindirilme derecesi }\end{array}$ & 10 & $64.67 \pm 1.98 \mathrm{a}$ & 9 & $69.95 \pm 4.05$ & 8 & $49.61 \pm 2.90 \mathrm{~b}$ & 9 & $26.16 \pm 4.57 \mathrm{c}$ \\
\hline
\end{tabular}

Ayn salırda farklı harfi taşıyan değgerler birbirinden farklı bulunmuştur $(p<0.05)$.

Tablo 10. Gruplarda liftik kalitesi ile ilgili değerler.

Table 10. Mean mohair quality values of groups.

\begin{tabular}{|c|c|c|c|c|c|c|c|c|c|}
\hline \multirow{2}{*}{$\begin{array}{l}\text { Yapağ kalitesi } \\
\text {. }\end{array}$} & & \multirow[b]{2}{*}{$n$} & \multirow[b]{2}{*}{ Kontrol grubu } & \multicolumn{6}{|c|}{ Deneme gruplar } \\
\hline & & & & $\mathrm{n}$ & 1 & $\mathrm{n}$ & 2 & $n$ & 3 \\
\hline \multirow[t]{2}{*}{ lncelik. $\mu$} & Arș. Bass. & 10 & $22.66 \pm 0.82$ & 10 & $23.63 \pm 0.73$ & 10) & $22.40 \pm 0.60$ & 10 & $22.64 \pm 0.46$ \\
\hline & Arş. Son & 10 & $22.53 \pm 0.49$ & 10 & $23.14 \pm 0.74$ & 8 & $23.12 \pm 1.14$ & 9 & $21.40 \pm 0.68$ \\
\hline \multirow[t]{2}{*}{ Ondulasyon. adet } & Arş. Baş & 10 & $3.96 \pm 0.39$ & 10 & $3.93 \pm 0.37$ & 10 & 4.7()$\pm 0.49$ & 10) & $4.86 \pm 0.43$ \\
\hline & Arş. Son & 10 & $5.97 \pm 0.42$ & 10 & $6.46 \pm 0.23$ & 8 & $6.86 \pm 0.97$ & 9 & $5.62 \pm 0.48^{\circ}$ \\
\hline \multirow[t]{2}{*}{ Uzunluk. cm } & Arș. Baş & 10 & $5.39 \pm 0.32$ & 10 & $5.56 \pm 0.39$ & 10 & $6.27 \pm 0.44$ & 10 & $5.69 \pm 0.29$ \\
\hline & Arş. Son & 10) & $7.66 \pm 0.36$ & 10) & $7.69 \pm 0.42$ & 8 & $8.11 \pm 0.62$ & 9 & $7.53 \pm 0.48$ \\
\hline
\end{tabular}

Gruplar arasında istatistiksel bir farklılık tespit edilememiştir.

nında çay atığ kullanılması ile günlük kaba yem tüketimi önenuli derecede azalmışur (Tablo 7).

Kontool, 1. ve 2. deneme gruplarma ait yemden yararlanma değcrleri (Tablo 8) belirlenmiştir. Araştırma süresince çok: düşük canlı ağırlık artışı gösteren 3. deneme gruhuna ail değerler ise hesaplanmamışır.

Indikatör olarak asitte erimeyen kuil miktannın kullanıldığı sindirim denemesinde kuru maddenin sindirilme dereceleri Tablo 9'da gösterilmiştir.

Deneme başında ve sonunda alınan yapağı örneklcrinde kalite ile ilgili parametrcler Tablo 10'da verilmişiır.

Araştırmada $\% 40$ f̧ay atıkları verilen 3 . deneme grubundaki hayvanların aşırı derecede ürkck oldukları görülnüiştür

Araşurmanın 26. ve 38. günlerinde 2 . deneme grubundan iki hayvan, araştırmanın 32. gününde ise 3 . denenıe grubundan bir hayvan ölmüşür. Ölen hayvanların rumen ve bağırsak içeriklerinde bol miktarda çay atıkları görülmüiştür.

\section{Tartışma ve Sonuç}

Çay atıklarının Akkaraman kuzulara belirli oranlarda yedirilmesinin, canlı ağırlık artışı, yem tüketimi, kuru madde sindirilme derecesi ve yapağı kalitesi üzerinc etkisini belirlemek amacıyla yapılan bu çalışnıada kaba yem olarak kullanılan çay atıkları ve yulaf hasılının ham besin maddelerine ait değerlerin (Tablo 3), Rize yöresinden temin edilen çay atıkları ile daha önce yapılan bir çalışmanın (10) bulgularına benzerlik gösterdiği belirlenmiştir. Bulgulardaki bu benzerlik atık materyalin ayn yöreden sağlanmasına bağlanabilir. Konwar ve ark (14) ise HP'yi \% 19.48, HY'yi \%1 1.37. HS'yi \%1 1.05. HK'y1 $\% 7.58$ şeklinde bulmuşlardır. Yapılan bir dizi çalı̧̧mada ise çay atıklarının ham protein değcrlerinin yaklaşık \%18 olduğu ifade edilmiştir $(7,11)$. Bu çalışmada clde edilen HP, HY, HS ve HK değerleri bazı dış kaynaklı literatür bulguları (11) ile genelde uyum göstermemektedir

Bu denemede kaba yem olarak kullanılan yulaf halsılı ve çay atıklarının tanen miktarları sırasıyla 2.58 vo 13.9 ppm olarak tespit edilmiştir (Tablo 4). Kunjikutty ve ark. (15) çay atıklarındaki tanen miktarını \%1.8; Konwar ve ark. (11) ise kafeini çıarılmış çay atıklarında bu degeri \%0.4-0.8 olarak bildirmektedirler. Yapilan bir diğer çalışmada (14) isc çay atıklarının \%6.3 oranında tannik asit kapsadığı belirtilmiştir. Ülkemizde yüruitiilen bir araşturmada ise (10) çay atıklarının kuru madde de \%7.89 tanen içerdiği ortaya konulmuşıur. Çay atıkları arasında tanen içerikleri bakınından ortaya çıkan farklılıklarm bitkilerin yetiştirildiği bölge, toprak ve çay bitkisinin çeşidinden kaynaklanabileceg̣i kabul edilebilir

$\mathrm{Bu}$ araştırmanın ikinci yarısında kaba yem olarak yulaf hasılının \%40'ı yerine çay atıklan verilen grupta elde edilen canlı ağırlık değgerleri yulaf hasılı (konırol). $\% 10$ ve \%20 oranında çay atığ tüketen gruplardan önemli derecede düşük bulunmuştur $(\mathrm{p}<0.05)$ (Tablo 5 ).

Konwar ve ark. (1.3) buzağı rasyonlarında $\% 39$ oranında kullanılan buğday kepeğgi yerine \%0,20 ve 30 oranında çay atıkları katılması ile 224 güinliik deneme süresinde grupların surasiyla $79.2,76.3$ ve $55.6 \mathrm{~kg}$ canl ağılık kazandığmı saptamışlardır. Prasad ve ark. (17) Jersey $x$ Sindhi stğır melezi rasyonlarında \%.3.3 oranındaki 
buğday kepeği yerine $\% 15$ ve 25 oranında çay atığı kaulmasının süt veriminde kontrol grubuna göre önemli derecede azalnaya neden olduğunu bildirmişlerdir.

Deneme süresince elde edilen günlük ortalama canlı ağıılık artışlarına (GOCAA) ilişkin değerlere (Tablo 6) toplu halde bakıldığında (0-56. günler) kaba yem olarak sadece yulaf hasılının verildiği kontrol grubu (148 g) ile kaba yem olarak yulaf hasılı + \%10 f̧ay atıkları kombinasyonu alan grupta (127 g) (deneme 1) GOCAA bakımından fark bulunmamıs, bu iki gruba ait değerlerin $\% 20$ ve 40 çay atığı verilen gruplardan (sırasıyla $93 \mathrm{~g}$; $0.4 \mathrm{~g}) ; \% 20$ çay atı̆ 1 verilen gruba ait değerin ise $\% 40$ çay atığı alan gruptan önemli derecede yüksck olduğu göruilmiiştür $(\mathrm{p}<0.05)$. Denemc süresince yapılan tartımlarda kontrol ve 1 . deneme grupları (\%10 çay atığ) arasında ortaya çıkan farklılıklarda, 0-56. gün değcrlerinin kontrol grubu lehine olduğu görülmekte ise de 42-56. gün tartumlannda 1 . deneme grubuna ait degerin (151 g), kontrol grubuna ait değerden (136 g) matcmatiksel olarak yüksek oluşu dikkat çekicidir. Bu durum özellikle hayvanların \%10 düzeyindeki çay atığına zaman içinde uyum sağladığımn bir göstergesi olarak kabul edilebilir. Deneme 2 ve 3 gruplannda benzer bir uyum gözlenememiştir.

Ananthasubramaniam ve ark. (1) 6-10 aylık yaştaki Jersey $x$ Sindhi melez. buzağlann rasyonlarına 200 gün süre ile katulan \%20 oranındaki çay atığının günlük canlı ağırlık artışı üzcrine olumsuz bir etkisinin olmadığını bildirmişlerdir. Oysa, yapılan bu çalışmada rasyona yulaf hasılı yerine \%20 oranında katılan çay atığı GOCAA'yı olumsuz yönde ctkilemiştir.

Gruplarda tüketilen günlük ortalama yem miktarları Tablo 7’de verilmiştir. Bu çalışmada kontrol ve deneme gruplarnnda araştırma süresince tüketilen günlük ortalama kaba yem niktarları sırasıyla 953, 899, 757 ve 393 gramdir. Grup yemlemesi uygulaması nedeni ile her ne kadar istatiksel bir degerlendirme yapılamamıs ise de yulaf hasılı + çay atığı kombinasyonu içcrisinde çay atığı payının artmasma bağlı olarak yem tüketiminin düştügü gözlenmiştir. Ancak, 1. deneme grubundaki hayvanlar çalışma süresince \%10 oranında verilen çay atığına adaplasyon göstermişler ve buna bağlı olarak kaba yem tiiketiminde düzenli bir artıs meydana gelmiştir (Tablo 7).

Konwar ve ark. (13) buzağılarda konsantre yemlerde buğday kepeği yerine \%20 ve 30 oranında çay atıkları katılması ile konsantre yem tuiketimlerini kontrol grubunda 368.14; çay atığı tüketen gruplarda ise sırasıyla 361.9 ve $332.1 \mathrm{~kg}$ olarak bulmuşlardır. Konwar ve ark. (12) yaptıklan bir başka çalışmada ise Haryana $x$ Jersey melezi sığırların rasyonlarına kafeini alınmış çay atığından \%20 oranına kadar katılmasının kuru madde tü- ketinini olumsuz yönde etkilemediğini bildirmişlerdir Bu çalışma sonuçlarının buzağı ve süt sığırları ile elde edilen bulgularla $(12,13)$ uyumlu olmamass kafeini alınmış çay atıklarının kullanılnıasına bağlanabilir.

Deneme süresince gruplarda $1 \mathrm{~kg}$ canlı ağırlık arışı için tüketilen kaba ve konsantre yen miktarları belirlenmiştir. Ancak, kaba yem olarak \%40 çay atı̆̆l verilen 3. deneme grubunda, ağırlık artışı elde edilemediğinden. yemden yararlanma oranı hesaplanamıamışır. Denemenin 0-56.günleri için kontrol ve diğer deneme gruplarında 1 kg canlı ağırlık artışı için tüketilen toplam yem mikıarları sırasıyla $9.662 ; 10.827$ ve $13.802 \mathrm{~kg}$ olarak bulunmuştur

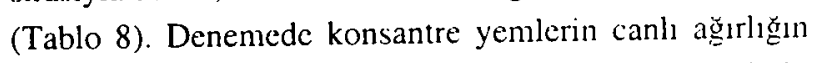
\%1.5'u ile sınırlandırılması elde edilen verilen de ğerlerin genelde yüksck bulunmasında etkili olmuştur. Diğer taraftan yulaf hasılı yerine kullanılan çay atığı miktarının artması yemden yararlanma oranını olumsuz yönde etkilemiştir.

Kuru maddenin sindirilme derecesi kontrol, 1., 2. ve 3. deneme gruplarında sırasıyla. \%64.67, 69.95, 49.61 ve 26.16 olarak tespit edilmiştir (Tablo 9). Bu sınuçlara göre yulaf hasılı $+\% 10$ çay atıkları kombinasyonu alan 1. deneme grubuna ait toplam kuru maddenin sindirilne derecesi $\% 20$ ve $\% 40$ çay atıkları verilen diğer deneme gruplarından önemli derecede yuiksek bulınmuştur $(\mathrm{p}<0.05)$.

Mosses ve ark. (16) 40:60 şeklindeki çay atığ + buğday kepeği kombinasyonu verilen melez sığırlarda kuru madde ve ham proteinin sindirilme derecesinin sadece bugday kepeği alan gruba göre önemli derecede düşük bulunduğunu bildirmişlerdir.

Kaba yem olarak farklı düzeylerde verilen çay atığının yapağı kalite kriterleri üzerine olumsuz etki yapmadığı görülmüştür (Tablo 10). Özellikle 3. deneme gru bunda kullanılan \%40 oranındaki f̧ay atığının canlı ağırlık üzerine yaptığı olumsuz etkinin yapağı kalitesine (ondulasyon, uzunluk ve incelik) yansımadığı ileri sürülebilir. Mcşe yaprağı ve süpürge darısı (Sorgum vulgare) gibi farklı tanen içeren kaynakların Ankara keçilerinde tiftik verim ve kalitesini olumsuz yönde etkilemediği bildirilmiştir (10).

Sonuç olarak, yaklaşık \%12-14 civarında ham protein oranına sahip olan çay atıkları içerdikleri bazı antinutrisyonel faktörler nedeniyle hayvan beslemede smurlı şekilde kullanılmalıdır. Yulaf hasılı yerine \%10 oranında kullanılan çay atı̆̆ı besi performansın,, toplam rasyon kuru maddesinin sindirilme derecesini ve hayvan sağlığını olumsuz yönde ctkilememiştir. Çay atığının \%20 oranında verilmesinin besi performansında natematiksel bir azalmaya neden olduğu, ayrıca toplan rasyon kuru maddesinin sindirilme derecesini önemli derecede dï- 
şiirdiugij ve hayvan sağlığını olumsuz etkilediği kanaatine varılmıştır. Rasyona \%40 oranında katılan çay atığ ise belirtilen parametrelerin tümünü öncmli derecede clumsuz yönde ctkilemiştir. Yulaf hasılı ilc değişik oranlarda kombine edilerek yedirilen çay atıklarının her iiç düzeyi de yapağı kalitesini olumsuz yönde etkilenıemiştir.

\section{Kaynaklar}

I. Ananthasubramaniam CR, Menachery M, Devasia PA, Nair AMC (1978): Effect of tea (Camellia sninensis, Linn) waste on growth in calves. Kerala J Vet Sci, 9, 228-234.

2. Anonim (1997): Çay /sletmeleri Genel Müdürlü̆ü Notlart. Rize.

3. AOAC (1984): Official Methods of Analysis Association of Official Analytical Chemists, Inc. Agrlington.

4. Baruah KK (1997): Effect of supplementation of decaffeinated tea waste on the yield and composition of milk in lactuting crossbred cows. Indian Vet J, 74, 480-482.

5. Begovic S, Duzic E, Sakirbegovic $\Lambda$, Tafro A (1978): Examination of amnase activity in ruminal contents and mucosa of goat fed oak leaves and during intraruminal application of 3 to $10 \%$ tannic acid. Veterinaria. Yugoslavi:a, 4. 445-457.

6. Crampton EW, Maynard LA (1938): The relation of cellulose and lignin content to nutritive value of animal feeds. J Nutr. 15, 383-395.

7. Daimary P, Saikia A, Baruah KK, Das PC, Saikia BN (1988): On possibility of including decaffeinated tea waste as a source of protein in the diet of broiler chicks. Indian J Anim Prod Manag, 4, 51-52.

8. Düzgüneş O, Kesici T, Gürbüz F (1983): lstatistik Metollurl I. Ankara Üniversitesi Ziratat Fakültesi Yayınları. No: 861. Ankara Üniversitesi Basımevi, Ankara.

9. İmeryüz F, Sandıkcığlu M (1968): Koyun Yetistiriciliğinde Yapă̆ı. Lalahan Zootckni Araşı̧rma Enstitiisü, Yaym No: 22.
10. Imik H, Seker E (1998): Farkl tanen karnaklarmun rifik keçilerinde yem lüketimi, canlı ağırlık arms,t, tiftik verimi ve kalitesi üzerine etkisi. Lalahan Hay Arș Ens Derg. 39. 85100.

11. Konwar BK, Ahmed HF, Nath NC, Das A (1986): Value of decaffeinated tea waste as a feed ingredient in swine ration. Indian Vct J, 63. 1031-1(135.

12. Konwar BK, $\Lambda$ hmed HF, Phukan B, Gohain $\Lambda K$, Rahman M (1991): Effect of feeding decaffeinated tea waste on the quantitiy and quality of milk in crossbred cows. Indian Vct J, 68. 55-59.

13. Konwar BK, Ahmed HF, Phukan B, Medhi AK (1992): Utilization of decaffeinated tea waste in crossbred calves. Indian Vet J, 69. 25-28.

14. Konwar BK, Mewdhi AK, Ahmed HF, Saikia A, Das PC (1985): Effect of feeding factory tea waste in starter chicks. Indian J Poultry Sci, 20, 122-123.

15. Kunjikutty N, Ramachandran P, Devasia PA, Thomas C'T, Nadakumaran M (1977): Evaluation of the feeding value of tea waste (Camellia thea) as an ingredient in the ration for growing pigs. Kerala J Vet Sci. 8. 127-132.

16. Mosses LS, Konward BK, Daj DR, Phukan B, Ahmet HT (1987): Nutritive value of decaffeinnated tea waste (DCTW) in cattle. Indian J Anim Nutr, 4. 59-60.

17. Prasad V, Subramanyam M, Ananthasubramaniam $\mathbf{C R}$ (1980): Evaluation of feeding value of teawaste for milk production in cows. 1. Effect on the quantity and quality of milk. Kerala J Vet Sci, 11, 192-198.

18. Sud RG, Dogra KK (1993): Chemical evaluation of spent tea leaves. Indian J Anim Nutr, 10. 259-260).

19. Van Soest PS, Robertson JB (1985): Analysis of Forages and Fibrous Foods. Corncll University.

Geliş tarihi: 12.3.2001/Kabul tarihi: 14.6.2001

Yazışma adresi:

Yrd. Doç. Dr. Halit lmik

Atatürk Üniversitesi, Veteriner Fakultesi

Hayvan Besleme ve Beslenme Hastaliklart Anabilim Dall

50. yll caddesi 25040, Erzurum

h.imik@excite.com. 